\title{
Norrie Syndrome
}

National Cancer Institute

\section{Source}

National Cancer Institute. Norrie Syndrome. NCI Thesaurus. Code C118634.

A rare, $\mathrm{X}$-linked recessive inherited syndrome caused by mutations in the NPD gene. It is characterized by developmental retinal abnormalities that result in blindness in male infants at birth or soon after birth. Additional manifestations include prog ressive hearing loss and developmental motor skills delays. 